$911.2: 551.58 / 524.2$

\author{
- $\mathbf{y} \mathbf{x}$ \\ ьвівський н ціон льний університет імені в н \\ вул. . орошенк , 41, м. ьвів, 79000, кр їн
}

икл дено результ ти дослідження просторового і ч сового (у меж х року) розподілу темпеp тури повітря н території міст ьвов н підст ві реєстр ції д т -логер ми. ведено топотермічну к рту ьвов .

лючові слов : топотермічні вл стивості, темпер тур повітря, дин мік темпер тури, темпер турні різниці, темпер турний гр дієнт, топотермічн к рт .

ід ч с розгляду топотермічних вл стивостей території ми свідомо уник ємо дискусійних термінів м кро-, мезо- т мікроклім т, топоклім т, оскільки йтиметься не про всі клім тичні х р ктеристики територій певної розмірності чи геоморфоелементу,

лише про темпер туру повітря, як формується під впливом б г тьох чинників, що діють н конкретному місцеположенні, з зн ючи ч сових змін ${ }^{1}$.

опотермічними вл стивостями н зив тимемо темпер турні х р ктеристики конкретного місця, невеликої гомогенної території. і вл стивості з лежні від теплообмінних процесів території. скільки ж територія не ізольов н від л ндш фтного середовищ, то темпер туру конкретного пункту формують чинники л ндш фтної ф ції, у якій цей пункт розт шов ний і функціонув ння якої з лежить від впливу урочищ, до якого н лежить ця ф ція. ідповідно, урочище є скл довою ч стиною ієр рхічного ряду вищих р нгів: місцевості, л ндш фту, $\mathrm{p}$ йону. огляду н це темпер тур конкретного пункту хоч і вл стив лише йому, проте з зн є впливів широкого оточення. овнішні впливи можн вв ж ти осл бленими, темпер туру конкретного місця - визн ч льною. одноч с територі льні відмінності був ють різними 3 умови різних погодних чи сезонних теплообмінних ситу цій у приземних ш р х тмосфери.

опотермічні пок зники з вжди м ють вир зне $n p$ ктичне зн чення, бо є одними 3 н йв жливіших вл стивостей середовищ життєдіяльності людини т й усіх геофізичних процесів. емпер турні х р ктеристики міст, у тому числі великих, м ють дод ткову пр ктичну в гу і впливи н функціонув ння інфр структури міст, особливо доріг т трубопроводів, $\mathrm{H}$ диференці цію ч стин міст 3 комфортністю прожив ння, 3 тр т н обігрів ння будинків, зрештою, н ціну житл в різних ч стин х міст .

дн к досліджень топоклім ту міст, зокрем ьвов, у ст. пр ктично не проводили, бо для цього необхідно було з діюв ти велику кількість кв ліфіков них спостеріг чів з відповідними прил д ми н трив лий ч с удень і вночі, у різну погоду зими чи літ , які б синхронно виконув ли вимірюв ння у б г тьох пункт х.

(C) $\mathrm{yx} ., 2010$

ерміни мікроклім т, мезо- м кроклім т, місцевий клім т, топоклім т розроблені б г тьм втор ми впродовж кількох десятків років $[4,5,6,9]$. 
ш мет - виявлення диференці ції темпер турних пок зників у різних регіон х ьвов, визн чення їхніх особливостей протягом року, різних пір року, з різної погоди, у різний ч с доби. ля цього потрібні синхронні вимірюв ння 3 ч стим повторенням протягом доби. ослідження в т кому розрізі у ьвові пр ктично не проводили, хоч історія розвитку метеорологічних вимірюв нь тут н лічує м йже 200 років.

ідомо, що вже 1811 р. ьвові ентузі сти метеорології (професор фізики і м тем тики - унзяк) розпоч ли регулярні метеорологічні вимірюв ння 3 допомогою прил дів (н той ч с ьвів перебув в у скл ді встро- горської імперії). 1864 по 1919 рр. метеорологічні вимірюв ння (тричі з добу) виконув ли при ьвівському університеті (під керівництвом проф. . ем н ). ід середини 1882 р. 3 пр цю-в л метеорологічн ст нція при ьвівській політехніці (спостеріг ч . ут к). 19191933 pр. у ьвові діяло три метеорологічні пункти - н вул. еленій, книлові т ев ндівці) [2]. 1920 р. при університеті з снов но нститут геофізики і метеорології під керівництвом - рцтовського. приходом р дянської вл ди у 1940 р. відкрито метеост нцію при льотному полі, як ф ктично поч л пр цюв ти з 1944 р. і діє до сьогодні ( ). етеост нцію університету з д ху головного корпусу було перенесено н огулянку, пізніше - в брошине (територія сільськогоспод рської дослідної ст нціi), потім - знову н огулянку, з 1969 р. вон функціонує в смт рюховичі як озтоцький л ндш фтно-геофізичний ст ціон р. p дянський ч с проведено т кож нетрив лі моніторингові вимірюв ння гідрометслужби в спеці льних мет левих к бінк х, розміщених у центрі міст і кількох $\mathrm{p}$ йон х ьвов . ороткоч сні вимірюв ння в періоди пр ктик студентів-геогр фів ьвівського університету хоч і зб г тили обізн ність про топоклім тичні особливості ьвов , проте не можуть претендув ти н високу достовірність.

тері ли перелічених вище вимірюв нь т результ ти їхного н лізу ч стково опубліков ні у н укових збірник х, бюлетенях т довідник х тих держ в, у підпорядкув нні яких перебув в ьвів у відповідний ч с, зокрем, у бюлетенях р ківського метеорологічного тов риств, що виходили у ідні, серії збірників “ оsmos” т ін. н чний внесок у вивчення клім ту з хідних обл стей кр їни, висотної клім тичної поясності рп т, т кож мікроклім ту ьвов зробив у 1950-1970 рр. доцент геогр фічного ф культету ьвівського університету . ндрі нов [1].

моногр фії “ лім т ьвов ”, що вийшл 1988 р. 3 ред кцією . біченк ( кр їнський н уково-дослідний гідрометеорологічний інститут ержкомгідромету) т узук ( олинський держ вний університет імені есі кр їнки), зроблено спробу сх p ктеризув ти темпер турні відмінності р йонів ьвов [2]. ведені в ній деякі “мікроклім тичні” вл стивості ьвов грунтуються, ймовірно, н експертних оцінк х, н дослідженнях . учерявого ( ьвівський лісотехнічний інститут), можливо з ч стковим використ нням н зв них вище джерел інформ ції (в моногр фії посил ння н конкретні джерел мікроклім тичної інформ ції нем ). описі мікроклім ту ьвов зн чну ув гу приділено впливу озеленення н мікроклім тичні вл стивості окремих пунктів ьвов .

и використовув ли винятково м теріли вл сних досліджень, отрим них у процесі вимірюв нь втом тичними й втономними електронними реєстр тор ми, розт шов ними в кількох $\mathrm{p}$ йон х ьвов . об з безпечити високу якість результ ту, н логічність темпер тури реєстр тор темпер турі ф ції, дослідник мусить дотримув тися певних критеріїв вибору конкретного пункту т пр вил інст ляції реєстр тор . 
одерні прил ди для мікроклім тичних досліджень в умов х рп т, ередк рп ття, оділля ми з стосовуємо з 2002 p. ${ }^{2}$ [3] (вперше в кр їні), і цей досвід з свідчує 6 г тосторонні перев ги т ких реєстр торів н д тр диційними метод ми з використ нням кл сичних вимірюв льних прил дів (психрометрів, термометрів, гігрометрів, що потребують присутності людей-спостеріг чів), ручних з писів у щоденник х чи бл нк х бо с мописців (термогр фів і гігрогр фів), які легко розрегульовуються, нест більні в пок з х і т кож потребують ч стих контрольних вимірюв нь і $з$ міни стрічок.

икорист ні н ми реєстр тори-д т логери фірми Gemini Data Loggers модифік ції Tinytag Ultra TGU - 1500 (рис. 1), призн чені для вимірюв ння темпер тури повітря 3 точністю $\pm 0,25^{\circ}$ у ді п зоні від -30 до $+50^{\circ}$ і відносної вологості повітря (у відсотк х) у ді п зоні від 0 до $95 \%$.

еєстр тор цього міні тюрного (розмір 72 х 60 х 53 мм, м с - 50 г) в рі нт прил ду може пр цюв ти втономно після відповідного прогр мув ння режиму його роботи з допомогою опцій спеці льної прогр ми GLM (Gemini Logger Manager).

ксим льн кількість вимірюв нь - до 8046 з п р лельною фікс цією повної д ти і точного (до секунди) ч су кожного вимірюв ння. стоту вимірюв нь можн 3 прогр мув ти з інтерв лом від 1 с до десяти днів. читув ння д них виконують 3 допомогою прогр ми GLM після вст новлення к бельного з'єдн ння реєстр тор 3 комп'ютером. чит ні д ні можуть бути експортов ні в типові комп'ютерні прогр ми, пристосов ні до опр цюв ння великих м сивів д них. ші д ні опр цьов ні в прогр мі Excel.

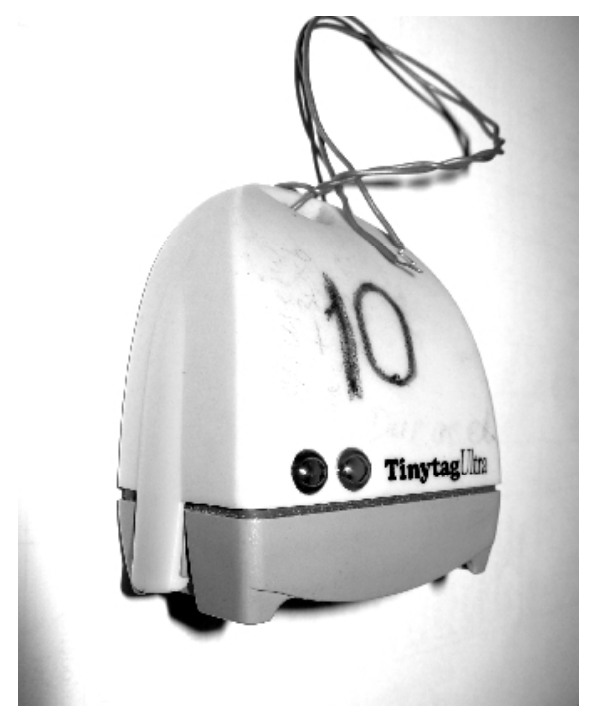

ис. 1. дин з реєстр торів Tinytag Ultra.

2 рил ди придб ні резденським технічним університетом для викон ння спільного укр їнсько-німецького проекту “ністер” під егідою , ( риж, FKZ 0339699), де відповід льним з топоклім тичні дослідження був втор. ісля з вершення проекту прил ди з лишили для використ ння у ьвівському університеті, 3 що висловлюємо вдячність німецьким уч сник м проекту. 
ля періоду досліджень реєстр тори з прогр мув ли н синхронну роботу 3 інтерв лом між відлік ми 30 хв. т кого прогр мув ння електронної п м'яті реєстр тор вист рч ло н 5,5 місяця роботи, тому для осягнення трив лого циклу потрібно було зчитув ти і перепрогр мув ти реєстр тори н новий ет п роботи. 3 г льному підсумку реєстр тори пр цюв ли від 1 лютого 2007 р. до 1 тр вня 2008 р. міщений стосовно поч тку к ленд рного року ст рт роботи реєстр торів зумовлений трудністю договорів про доступність до місць інст ляції прил дів н прив тних територіях.

ля виявлення т оцінки розкиду зн чень, що виникли під ч с обчисленння середніх річних темпер тур через невідповідність періоду н ших спостережень 3 періодом к ленд рного року скл дено т бл. 1. к б чимо, у чотирьох в рі нт х обчислення середньорічних зн чень темпер тури повітря отрим ні зн чення відхиляються м ло, пр ктично в меж х точності вимірюв ння, що з свідчує відсутність впливу з стосов ного обр хунку осереднених величин з обр ні послідовно 12 місяців у порівнянні $з$ к ленд рним роком.

блиця 1

ередні річні темпер тури повітря у ьвові з різні періоди 2007-2008 pp.

\begin{tabular}{|c|c|c|c|c|c|c|}
\hline озиції обчислень & \multicolumn{2}{|r|}{ йони міст } & \multicolumn{4}{|c|}{ ьвов , де проводили вимірюв ння } \\
\hline еріоди обчислень & ентр & йорівк & ихів & ульп рків & ев ндівк & боїщ \\
\hline $1.02 .07-1.02 .08$ & 11,46 & 9,50 & 9,74 & 10,23 & 9,63 & 10,01 \\
\hline $1.03 .07-1.03 .08$ & 11,60 & 9,71 & 9,93 & 10,40 & 9,88 & 10,19 \\
\hline $1.04 .07-1.04 .08$ & 11,34 & 9,53 & 9,74 & 10,18 & 9,75 & 9,96 \\
\hline $1.05 .07-1.05 .08$ & 11,31 & 9,55 & 9,82 & 10,18 & 9,88 & 9,99 \\
\hline ереднє зн чення & 11,43 & 9,57 & 9,81 & 10,25 & 9,79 & 10,04 \\
\hline $\begin{array}{l}\text { ереднє зн чення } \\
3 \text { округлене } \\
\end{array}$ & 11,4 & 9,6 & 9,8 & 10,2 & 9,8 & 10,0 \\
\hline т нд ртне відхилення & 0,11 & 0,08 & 0,08 & 0,09 & 0,10 & 0,09 \\
\hline в др тичне відхилення & 0,05 & 0,03 & 0,02 & 0,03 & 0,04 & 0,03 \\
\hline
\end{tabular}

ибір місць розт шув ння реєстр торів грунтув вся н вр хув нні л ндш фтної структури ьвов , як є досить скл дною вже н рівні р нгу “л ндш фт” через те, що ьвів розміщений н конт кті п'яти індивіду льних л ндш фтів: смового обужжя в північній ч стині, озточчя - в північно-з хідній і південно-східній, ьвівського пл то у південній т ородоцько- ирецького - у південно-з хідній ч стині.

ля вст новлення реєстр тор обир ли приблизно центр ч стини л ндш фту, що увійшл в межі міст . ісцями інст ляції прил дів слугув ли відкриті 6 лкони другого поверху з північного боку житлових будинків, що д в ло змогу з хистити прил ди від н грів ння прямими сонячними променями і вберегти їх від н дміру “цік вих” мешк нців міст т від в нд лів ${ }^{3}$.

3 рин гідно вир ж ю вдячність тим пр цівник м т випускник м університету, їхнім сусід м, які погодились н інст ляцію при їх помешк ннях н укових прил дів, с ме: есі стровській, еоніду удковському, т лі і иросл ву ністрянським, юбі й лекс ндру укіним, юдмилі остів, есі і теп ну рг, лі ізяр, рії і иросл ву інкевич м. 
еєстр тор 1 був розт шов ний у центрі ьвов непод лік від оперного те тру. ентр міст розміщений в улоговині, сформов ній виток ми олтви, з якою конт ктують підвищені л ндш фти озточчя і ьвівського пл то. бсолютні висоти центр льної ч стини міст дорівнюють 280-290 м і поступово знижуються лише в долині олтви в н прямку н р йон міст, який н зив ють “боїщ”, що н лежить до смового обужжя. ме т м, серед м лоповерхової з будови прив тного сектор розт шов ний реєстр тор 6. йвищим 3 бсолютною висотою $(370$ м) р йоном міської з будови 3 прилеглими лісоп рк ми є йорівк (вул. січн), де інст льов нј реєстр тор 2. ещо нижче, посеред досить густої б г топоверхової з будови ихов (ринок ихівський- скр ) вст новлено реєстр тор № 3. еєстр тор 4 уст новлений у ульп ркові серед м лоповерхової прив тної з будови з с д ми, що н лежить до хвилястої поверхні ьвівського пл то ( устомитівського л ндш фту). еєстр тор 5 пр цюв в н ев ндівці серед різноповерхової з будови - близько від з ліснених горбів озточчя і з болоченої ілогорщо- льчицької долини ( ородоцько- ирецький л ндш ф).

н ліз пок зників роботи реєстр торів підтвердив їх н дійність і точність, особливо вр зі реєстр ції темпер тури. ідносн вологість повітря з реєстров н зі зн чними відхиленнями від норм льної роботи, які фіксов ні у порівняно пл вному реєстрі пок зників р птовими змін ми до рівня 0 чи $100 \%$ ). ожливо, що т кі відхилення могли бути зумовлені проникненням дрібних ком х до чутливого елемент вологості повітря. ідтвердженням цього був ф кт виявлення плівкових гнізд і коконів с ме в тих реєстр торів, які д в ли дуже сумнівні пок зники вологості повітря.

сю сукупність д них критично про н лізов но, “розбито” по місяцях для обчислення середньомісячних зн чень, розділено й осереднено з пор ми року, погод , т кож посортов но з зн ченнями пок зників для виявлення їхнього кількісного співвідношення.

зн чимо, що клім т ьвов, як і всієї емлі, н ч с проведених досліджень 3 зн в в потепління. я тенденція бул н йвир знішою в другій половині ст., про що вже зг д но 4 , і мінімізув л ся н поч тку ст. е призвело до того, що б г торічні норми пок зників темпер тури повітря виявилися з вищеними у період реєстр ції приблизно н 3-4 ${ }^{\circ}$ (дуже б г то, одн к т кий ф кт з фіксов но). гідно 3 суч сними розр хунковими прогноз ми, потепління з кінчилось, його з мінять зн чні темпер турні колив ння [7].

ередні річні т екстрем льні мінім льні і м ксим льні темпер тури з період реєстр ції в різних регіон х ьвов з свідчують т ке:

- середня річн темпер тур в різних р йон х ьвов виявил ся різною і змінюв л ся від $\left(9,6-9,8^{\circ}\right.$ н окр їн х міст до $11,4^{\circ}$ у центрі (т бл. 2). $1^{\circ}$ нижчою, ніж у центрі міст, бул середньорічн темпер тур повітря в ульп ркові т боїщ $\mathrm{x}-$ це гіпсометрично знижені р йони, до яких приляг ють сільськогоспод рські угіддя.

4 ричини глоб льних змін клім ту пов'язуємо не тільки з п рниковим ефектом від збільшення вмісту 2 т 3 бруднення в тмосфері емлі, й з природними колив ннями сонячної ктивності т ф ктором NAO (північно тл нтичн осциляція). ротягом 1960-2000 рр. темпер тур повітря підвищил ся н $3^{\circ} \quad 3$ розр хункової норми для ьвов [3, 7] $-0,8^{\circ} / 100$ років. поч тку ст. потепління дещо ст білізув лося i, згідно з розр хунк ми професор рш вського університету . орички, н явн тенденція повинн змінити свій зн к, тобто повинне розпоч тися похолод ння, яке трив тиме до середини ст. [7]. 
йнижч середньорічн темпер тури з фіксов н н йорівці, ихові т ев ндівці. о всіх трьох приляг ють лісові м сиви озточчя. йорівк м $є$ н йбільшу бсолютну висоту (370 м), дещо нижчими є ихів т ев ндівк . о гіпсометрично зниженої ев ндівки примик ють з болочені зниження;

- екстрем льн м ксим льн темпер тур повітря у ьвові в липні бул високою і ст новил $33,9-38,0^{\circ}$, одн к н ст в л не синхронно, що свідчить про місцеві причини формув ння екстрем льних м ксимумів т несинхронне 3 тінення ч стин міст хм р ми. йвищі екстрем льні темпер тури були в центрі міст т н ульп ркові;

- екстрем льн мінім льн темпер тур повітря у ьвові в рік реєстр ції опуск л ся лише до $13,9-16,5^{\circ}$ морозу. йхолоднішим виявився знову ж т ки р йон ульп рков , н йтеплішим - центр міст . ізниця між ними невелик $\left(3^{\circ}\right)$, проте й відст нь між ними т кож м л -лише 4 км;

ередні т екстрем льні зн чення темпер тури повітря у р йон х ьвов 3 період спостережень 2007-2008 pp.

\begin{tabular}{||c|r|r|r|r|r|r||}
\hline \multirow{2}{*}{ озиції обчислень } & \multicolumn{5}{|c||}{ йони міст } \\
& \multicolumn{1}{|c|}{ ьвов , де проводили вимірюв ння } \\
\cline { 2 - 7 } & ентр & йорівк & \multicolumn{1}{c||}{ ихів } & ульп рків & ев ндівк & боїщ \\
\hline ередні зн чення & $\mathbf{1 1 , 4}$ & $\mathbf{9 , 6}$ & $\mathbf{9 , 8}$ & $\mathbf{1 0 , 2}$ & $\mathbf{9 , 8}$ & $\mathbf{1 0 , 0}$ \\
\hline ксим льні зн чення & 37,50 & 33,90 & 37,10 & 38,00 & 34,80 & 35,70 \\
\hline інім льні зн чення & $-13,90$ & $-16,50$ & $-14,80$ & $-16,50$ & $-14,20$ & $-15,60$ \\
\hline
\end{tabular}

рис. 2 зобр жено криві середніх річних т середньомісячних зн чень темпер тури повітря в січні т липні у різних р йон х міст . ік во і, можливо, симптом тично для ьвов, що середня 3 мінім льних темпер тур липня, середня $з$ м ксим льних темпер тур січня т середньорічн темпер тур пр ктично збіглись в усіх пункт х реєстр ції.

ередня темпер тур повітря з липень у рік н ших спостережень (2007) виявил сь досить високою і перевищув л н ч стки гр дус рівень $20^{\circ}$ (з б г торічної норми $\left.18,3^{\circ}\right)$. ередня темпер тур січня бул 3 вищен ще більше - приблизно н $4^{\circ}, \mathrm{i}$ колив л сь біля нульового зн чення (з 6 г торічної норми $4^{\circ}$ морозу). кий ф кт відповід є відомій специфіці глоб льного потепління н терен х ольщі й кр їни, де середньорічн темпер тур повітря підвищується, головно, з вдяки потеплінню зим [3]. енше цю тенденцію помітно в зміні темпер тури повітря в липні і влітку з г лом (див. рис. 2).

изн чені н ми середні зн чення темпер тури повітря різних р йонів ьвов в меж х пір року т кож виявили суттєві різниці, подібні до опис них вище для середніх т екстрем льних темпер тур: улітку н йтеплішими були центр міст i ульп рків, взимку - центр міст і ихів - очевидно, з причин н йбільшої густоти з будови і комун льних викидів тепл . йхолоднішими взимку були йорівк - через м ксим льну серед пунктів реєстр ції бсолютну висоту р йону, т ульп рків - імовірно, через близькість до відкритих просторів з полями.

есн 3 період н ших спостережень (2007 р.) виявил ся теплішою, ніж осінь (рис. 3), хоч обидв ці періоди н леж ть до перехідних, і підвищення темпер тури до літ не повинно бути більшим, ніж зниження темпер тури від літ до зими. кі нерів- 
ності виник ють через незбіг ння пір року в конкретний рік (р ння чи пізня весн тощо) з середньост тистичними д т ми н ст ння і з кінчення пір року.

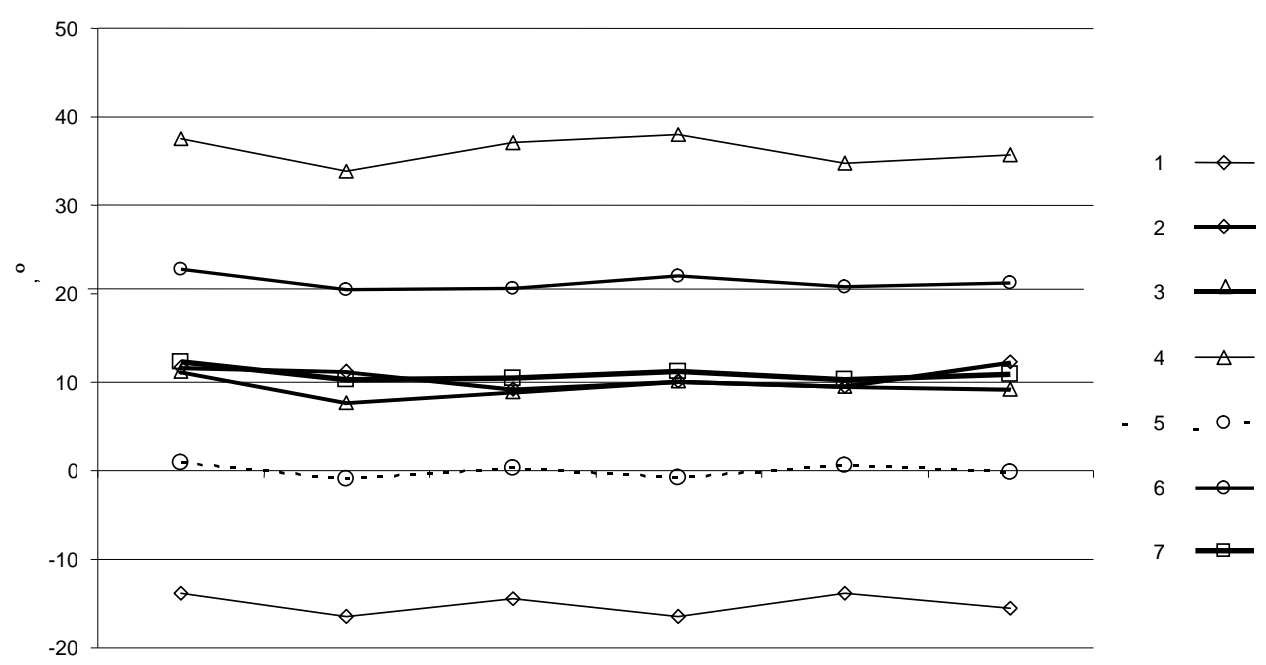

ис. 2. інім льні $(1,2)$, м ксим льні $(3,4)$ т середні (5-7) зн чення темпер тури повітря у різних р йон х ьвов 3 період реєстр ціїі (1.02.07-1.02.08): 1, 3, 5 січня; 2, 4, 6 липня, 7 - річні.

роведені н ми дослідження д т поч тку і з кінчення пір року н підст ві критеріїв строномічних, метеорологічних, геофізичних $\mathrm{T}$ к ленд рних 3 м тері л ми спостережень озтоцького л ндш фтно-геофізичного ст ціон ру д ли змогу виявити, що н йближчими до істини були критерії геофізичні (з х р ктером кривих дин міки метеорологічних пок зників), які ст тистично виявилися н ближеними до д т к ленд рного розподілу року н весняні, літні, осінні т зимові місяці (по три) 3 відхиленнями н один-три дні.

iк во, що в р зі геофізичного способу визн чення темпер тур для періоду н ших топотермічних реєстр цій результ ти виявилися відмінними від н ведених вище пок зників, обчислених 3 к ленд рним критерієм визн чення пір року, особливо для перехідних сезонів - весни й осені, с ме: темпер тури літ і зими розр хов ні 3 к ленд рною н лежністю повних місяців до пір року і 3 геофізичним критерієм пр ктично не відрізняються (рис. 4). вп ки, для перехідних пір року м ємо суттєві різниці в р зі різних способів визн чення трив лості пір року, с ме: к ленд рний спосіб д є з вищений пок зник темпер тури для весни і з нижений - для осені. вип дку геофізичного способу визн чення (з тенденцією ходу кривих) весни й осені середні зн чення темпер тури з ці періоди пр ктично збіг ються. жливо т кож, що вони розт шув лися симетрично поміж кривими для к ленд рних сезонів. тже, підвищення темпер тури н весні т іiї зниження восени виявилися зб л нсов ними, що, відповідно підтверджує пр вильність з пропонов ного н ми способу визн чення ч сових меж сезонів (геофізичний - 3 ходом кривих).

рис. 5 зобр жено періоди ст більності т мінливості темпер турних переходів протягом року, с ме: літо і зим вигляд ють період ми ст більності темпер тури 3 широкими полями поміж кривими певних темпер тур (від -2 до +2 для зими і 20-22 для 


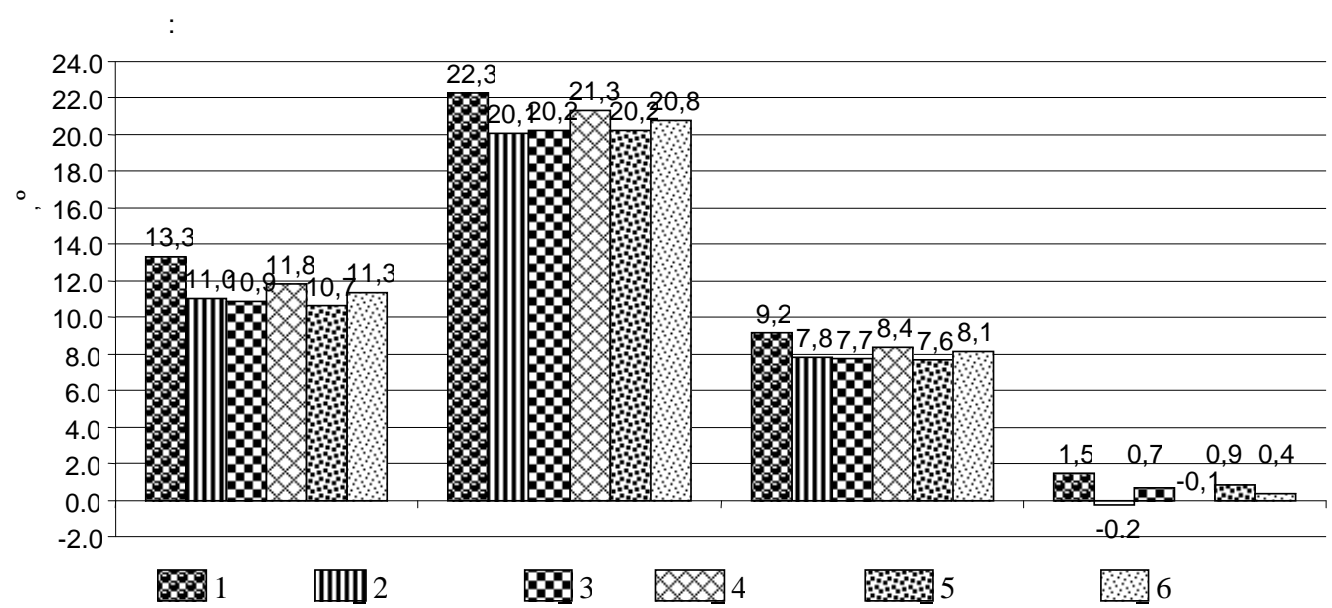

ис. 3. ередня з пори року темпер тур повітря у р йон х ьвов в 2007-2008 pp.:

1 - ентр; 2 - м йорівк ; 3 - ихів; 4 - ульп рків; 5 - ев ндівк ; 6- боїщ .

літ ), весні т осені вл стиві швидкі зміни темпер тур т відповідних їм кривих. йшвидші зміни з період вимірюв нь відбув лись від середини серпня до середини вересня, у першій половині листоп д т від середини лютого до середини березня. еяке сповільнення осіннього зниження темпер тури було у жовтні, сповільнення весняного підвищення - у березні-квітні. ші спостереження д ють підст ви вв ж ти, що опис н дин мік темпер тури 3 період спостережень $є$ досить х р ктерною для річної дин міки з г лом (рис. 6).

ізниці середньомісячних темпер тур у меж х ьвов т кож невеликі (від 0,5 до $3,5^{\circ}$ ), одн к зн чно більші, ніж різниці середньорічних темпер тур. х ми позн чили н ді гр мі перевищень темпер тури для центр міст, де осереднені темпер тури 3 вжди вищі від н логічно обчислених темпер тур інших р йонів міст (див. рис. 5). т кого підходу виявлення різниць великі зн чення з свідчув тимуть, що відповідний $\mathrm{p}$ йон холодніший, м лі зн чення різниць, - що $\mathrm{p}$ йон м ло відст $є$ від центр міст в прогрів нні, чи подібний до нього в процес х вистиг ння.

иявилося, що різниці середньомісячних темпер тур дуже нест більні просторово і в ч сі (від місяця до місяця). Г лом н йбільші різниці з центром міст м ють ев ндівк , ихів т йорівк - н йвідд леніші і гіпсометрично н йвищі т холодні $\mathrm{p}$ йони. йменші різниці були між центром міст і р йоном ульп рков (рис. 7).

еред к ленд рних місяців н йбільші в усіх р йон х міст виник ли у вес-няний т літній періоди, н йменші різниці - у зимовий період. ксим льне зн чення різниці середньомісячної темпер тури було в квітні н ев ндівці $\left(3,3^{\circ}\right)$. исокі $\left(2,3-2,7^{\circ}\right)$ квітневі різниці з фіксов ні т кож у р йон х ихів і боїщ . е озн ч є, що н зв ні p йони повільно прогрів ються після зими. исокі різниці середньомісячної темпер тури між центром міст і ев ндівкою т иховим можн пояснити близькістю до них лісових м сивів, які згл джують хід темпер тури протягом доби, в підсумку і місяця т року. боїщ опинилися в цій групі через сусідство з болотистими територіями, що спричиняють подібний ефект. 


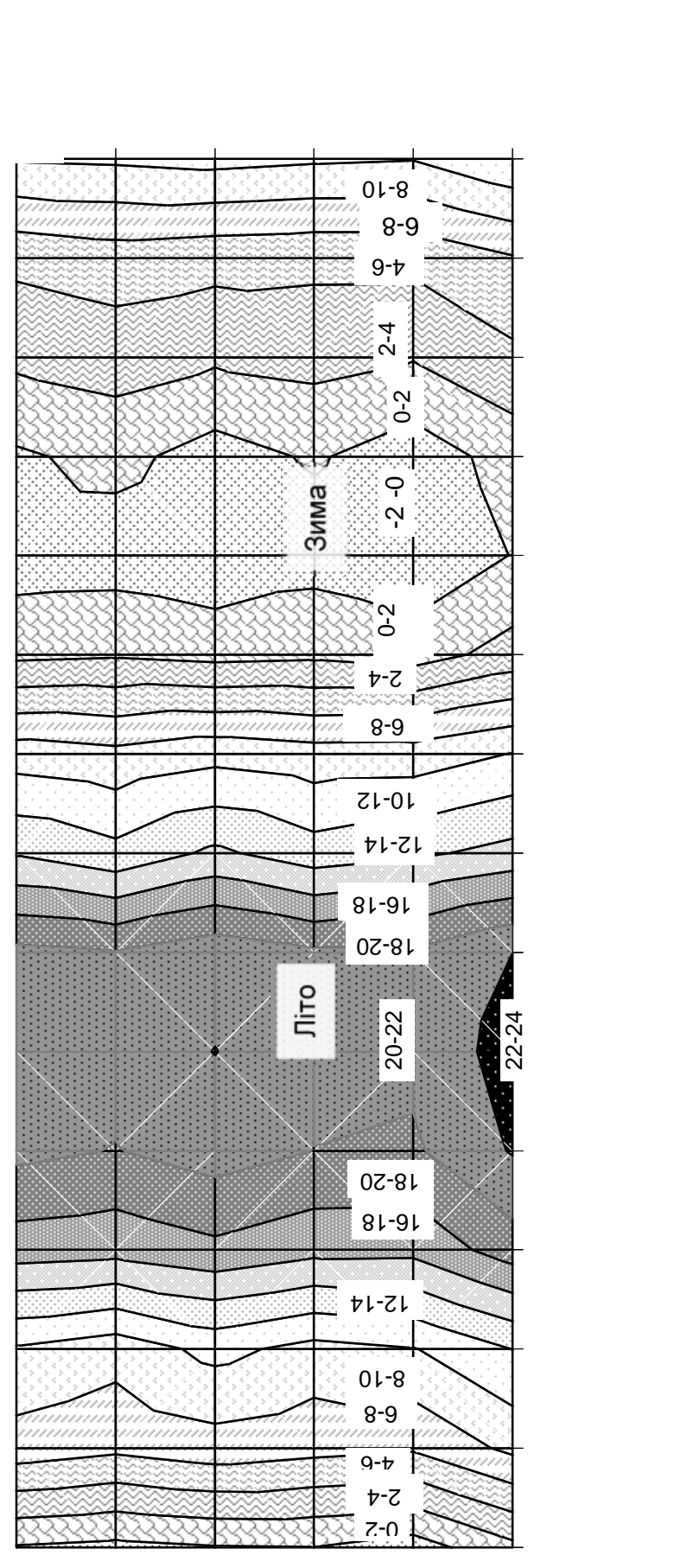




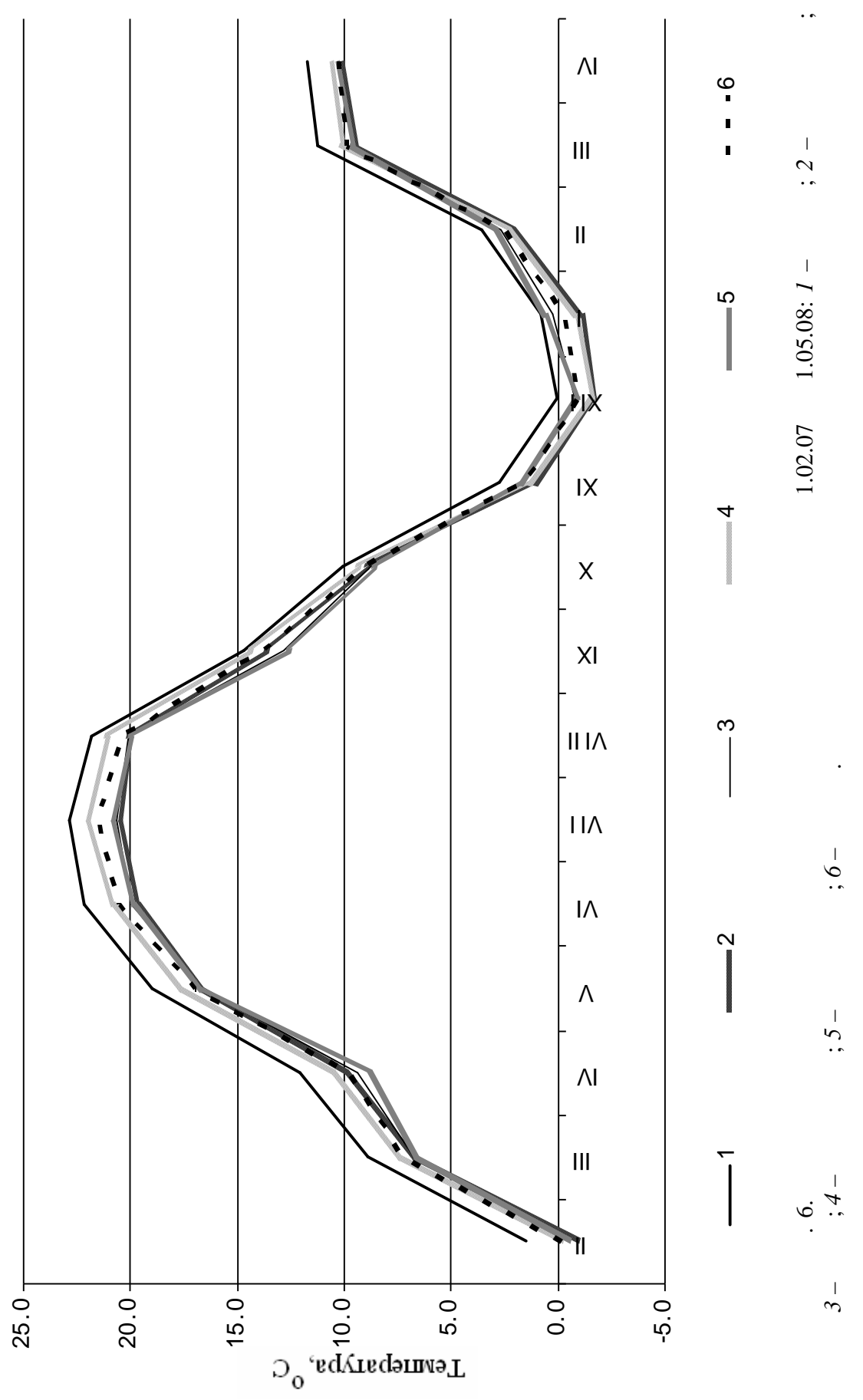




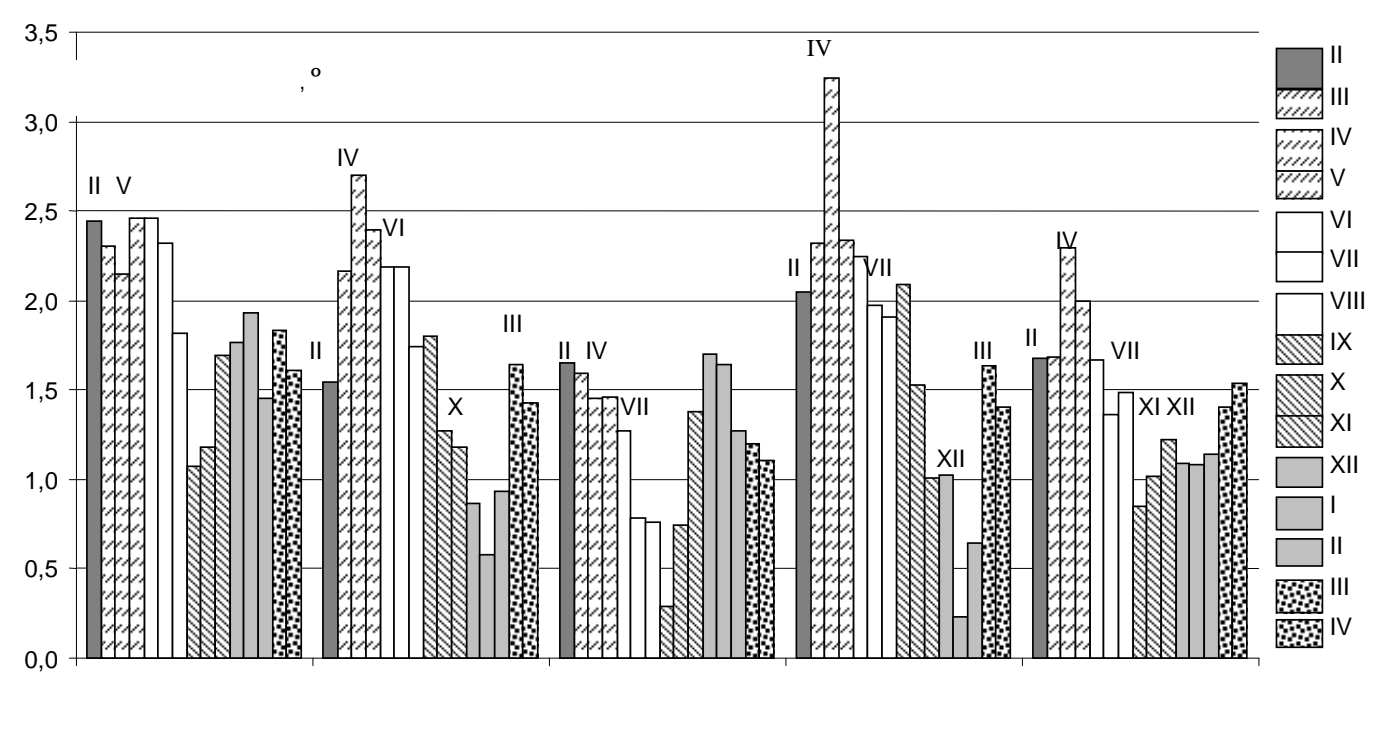

ис. 7. ізниці середньомісячної темпер тури (в ${ }^{\circ}$ ) повітря між центром т р йон ми ьвов .

p зі порівняння темпер тури повітря в різних $\mathrm{p}$ йон $\mathrm{x}$ ьвов 3 коротші періоди - н прикл д, у меж х трив лості певної погоди, виявляється ще більше дет лей місцевих впливів. р ктер кривих ст є більш пульс ційним, особливо в дні з мінливою хм рністю. йбільші різниці виник ють у дні з теплою нтициклон льною погодою, н йменші - у дні з вітряною циклон льною погодою.

ід ч с н йхолоднішої у 2008 р. погоди дин мік кривих ходу темпер тури повіт-ря з свідчил очікув ну ситу цію, коли протягом денних і нічних годин 3 добовою мплітудою $10-16^{\circ}$ ді п зон розкиду з фіксов них зн чень різниць вкл д вся у $2-3^{\circ}$, причому в холодні ночі територі льні різниці були меншими (рис. 8). ік во, що в холодні ночі н йтеплішими р йон ми ьвов були ев ндівк і центр міст .

йхолоднішими в цю морозну погоду виявились йорівк i ульп рків: йорівк через високий гіпсометричний рівень, ульп рків - через приляг ння до відкритих безлісих просторів устомитівського л ндш фту.

продовж ж ркої нтициклон льної погоди спостережено н йбільші добові мплітуди (до $20^{\circ}$ ) і н йбільші просторові відмінності темпер тури повітря. ентр льн ч стин міст бул н йтеплішою протягом дня і ночі. йорівк виявил сь, відповідно, н йхолоднішою. післяполудневі години різниця темпер тури повітря між центр льною ч стиною міст, яке ще н грів лось від сонця і від н грітого 3 день к меню будинків т сф льту, т між йорівкою (відст нь 4 км), як вже поч л охолоджув тись, досяг л 9-10 (рис. 9), в окремі моменти н віть $12^{\circ}$. е дуже велик різниця, як безперечно повинн виявлятись в ктивіз ції конвективних т двективних рухів повітря в меж х міст, посиленні впливу “міського теплового остров ”. ідповідно, цей вплив вир ж ється зменшенням кількості оп дів т грозової діяльності н д центр льною ч стиною міст і збільшенні ії по периферії, т кож створенні вир зно дискомфортних умов у н йбільш з будов ному і перен сиченому тр нспортом центрі міст , 
де $\mathrm{p}$ зі формув ння стійкої стр тифік ції приземних ш рів повітря можуть утворюв тися смоги.

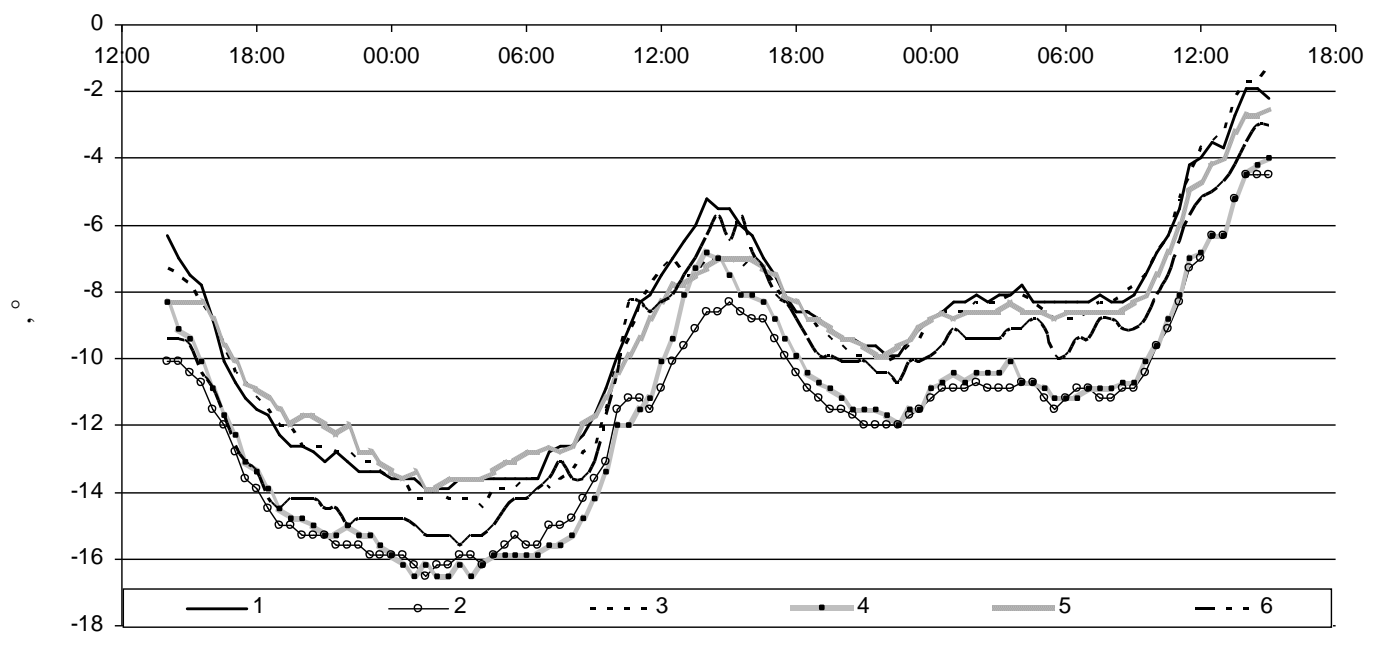

ис. 8. озподіл темпер тури повітря у р йон х ьвов в н йхолоднішу добу 2008 p. (5 січня) т в н ступні дні потепління (6,7 січня): 1 - ентр; 2 - йорівк ; $3-$ ихів; $4-$ ульп рків; 5 - ев ндівк ; 6 - боїщ .

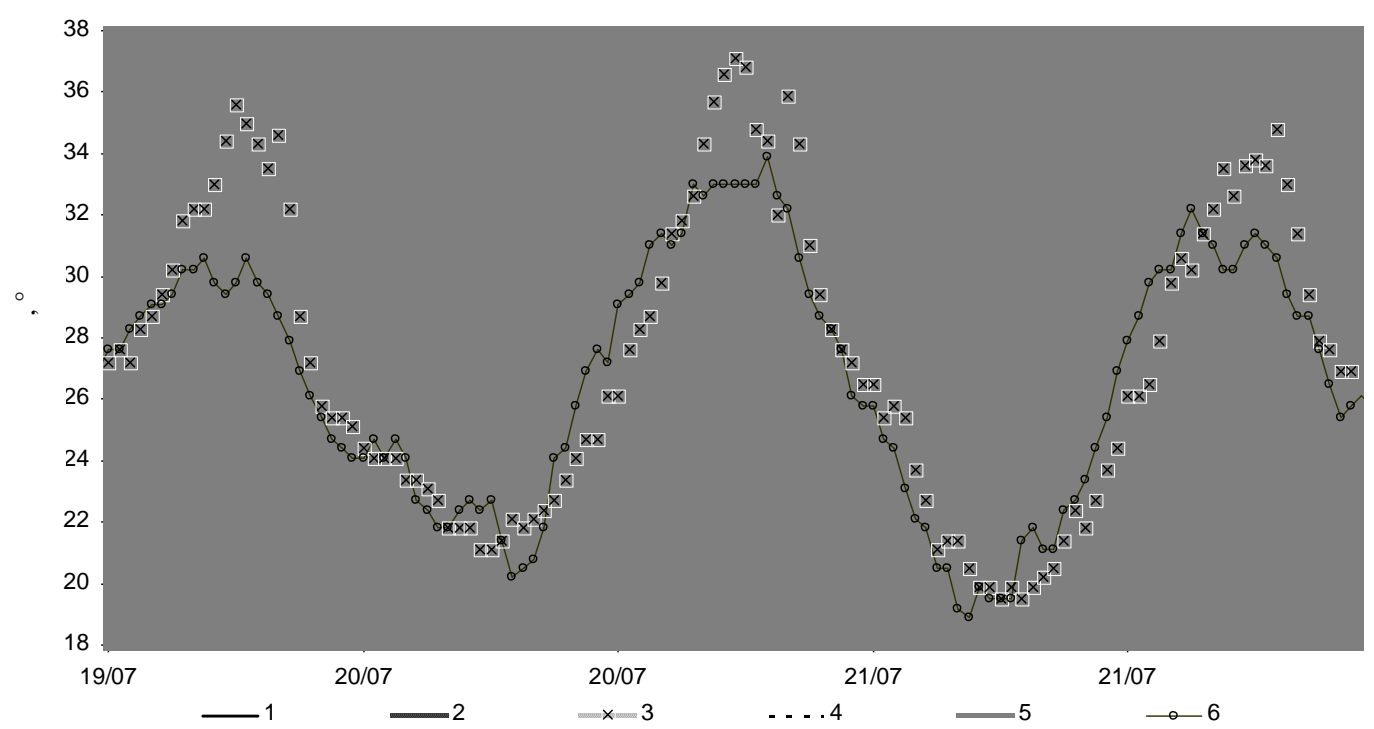

ис. 9. ід темпер тури повітря у р йон х ьвов в ж рку погоду липня 2007 р.: 1 - ентр; 2 - йорівк ; 3 - ихів; 4- ульп рків; 5 - ев ндівк ; 6- боїщ . 
н ліз ходу темпер тури повітря у р зі зміни повітряних м с д в змогу виявити несинхронність, різну інтенсивність змін т інші специфічності цього процесу (прояви темпер турних інверсій) у меж х ьвов . і відмінності дуже різном нітні й з леж ть від модифік цій поля темпер тури у ьвові т н його околицях, н пряму переміщення повітряних м с, тенденції зміни погоди (зміни тепл н холод чи н вп ки), хм рності т специфіки 6 ричних систем. рис. 10 пок з но лише один в рі нт зміни темпер тури в регіоні в р зі повільного н пливу холодного повітря з півночі т відобр жено ії як різницю темпер тури повітря між центром і двом близько розт шов ними р йон ми -

йорівкою т иховом. К б чимо, у перші чотири дні темпер тур повітря змінюв л сь під впливом місцевого вихолодження т денного прогрів ння і з г лом м ло $\left(0,5-1,5^{\circ}\right)$ відрізнял сь між собою, що х р ктерно для зимового періоду. ост нні дв дні вихолодження з зн в споч тку р йон йорівки, де різниці темпер тури зросли до $2,5-3,0^{\circ}$, тоді як різниця темпер тури між центром і иховом н віть дещо зменшил сь. рі нтів тр нсформ ції поля темпер тури в меж х міст виявлено б г то, що з свідчує різном нітність конкретних топотермічних ситу цій і побутовопр ктичну сумнівність потреби їхнього опису (окрім з'ясув ння теорії причиннон слідкових геофізичних зв'язків, що може бути предметом спеці льного розгляду).

и пр гнули сх р ктеризув ти середньост тистичну к ртину темпер турного поля міст ьвов, тому спробув ли зобр зити їі к ртогр фічно. ля побудови т кої к рти (рис. 11) використ но прогр му Map-Info (технічно-комп’ютерну ч стину формув ння к рти викон в л бор нт к федри фізичної геогр фії . рпець).

ихідним м тері лом слугув ли середньорічні зн чення темпер тури повітря в н ших пункт х втом тичної реєстр ції, середньорічне зн чення темпер тури повітря (з одн ковий 3 реєстр тор ми ч с) н озтоцькому л ндш фтно-геофізичному ст ціон рі т середньорічн темпер тур з метеост нції ьвівського еропорту книлів, що безпосередньо приляг є до міст . ртогр фічною основою для лок ліз ції пунктів дослідження ст л топогр фічн к рт ьвов й околиць м сшт бу 1:100 000, вид ння 2007 p.

цій підст ві споч тку створено к ртосхему темпер турного поля з використ нням звич йної просторової множинної лінійної інтерполяції, тобто без ур хув ння гіпсометричної поверхні (див. рис. 11).

же н цій к ртосхемі (див. рис. 11) вир зно виділил ся зон тепл в центр льній ч стині міст, як поступово зменшув л ся до півдня і з ходу, тобто до ульп рков , книлов , боїщ, ихов , проте швидко переходил у холоднішу зону йорівки (н північному сході), ев ндівки (н з хід від центр ). ме в двох ост нніх р йон х явно простежено вплив височини озточчя 3 лісненістю і зн чними бсолютними висот ми.

ля досягнення ре льнішого результ ту з ур хув нням впливу рельєфу н розподіл темпер тури ми визн чили місцеві вертик льні темпер турні гр дієнти між низьким центром міст т н вколишніми піднятими чи зниженими рівнями н підст ві середньорічних зн чень темпер тури повітря у цих пункт х.

трим ний н ми середній гр дієнт зн чно перевищув в відомий норм льний вертик льний темпер турний гр дієнт у нен сиченому повітрі й дорівнюв в $2^{\circ}$ н 100 м висоти, бо $0,2^{\circ}$ н 10 м. т ким результ том треб погодитися, оскільки вихідними для розр хунків д ними були з реєстров ні відліки високої точності по м йже 22000 н кожному з пунктів. формув ння цих відліків вплинули геогр фічні чинники: низький гіпсометричний рівень центру міст ( ьвівськ улоговин ), т осл блен 
його вентиляція, спричинен з тіненням прилеглими височин ми, густою з будовою центр ьвов .

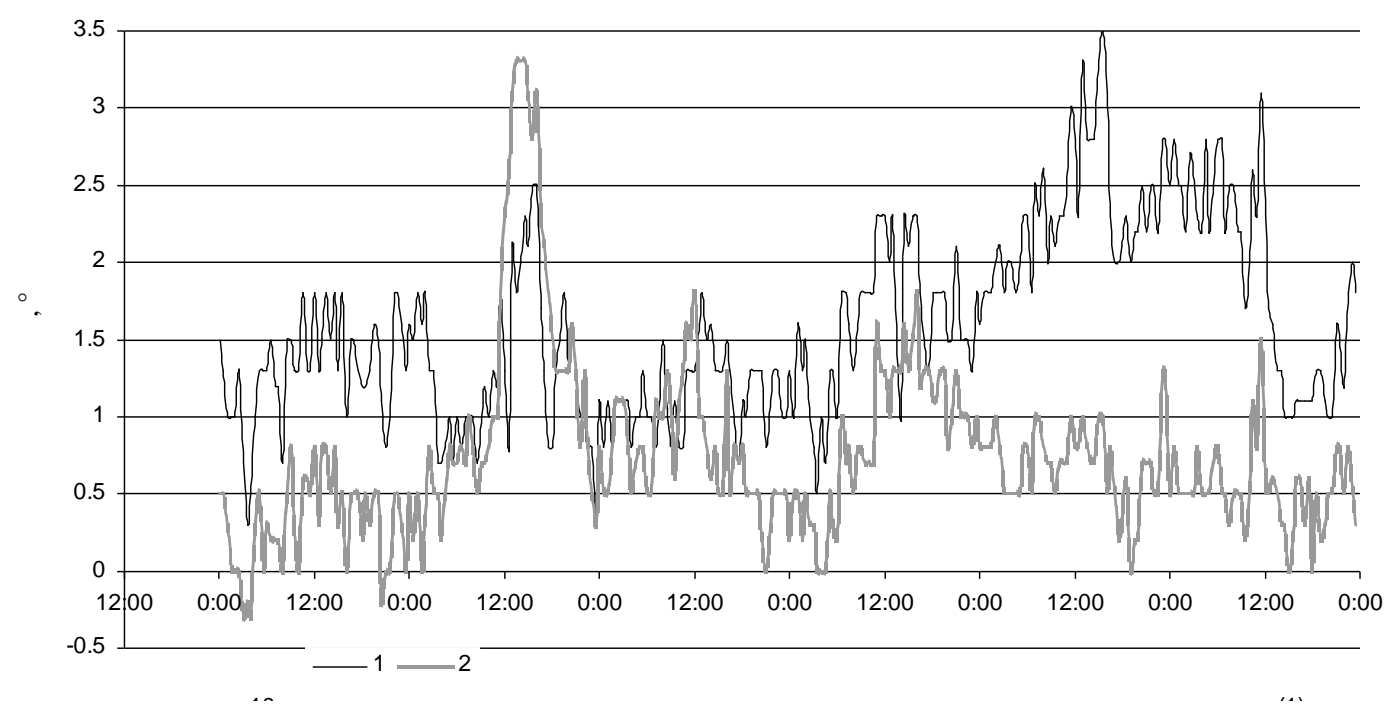

ис. 10. еревищення темпер тури повітря в центрі ьвов н д цим же п р метром у пункт х січн (1) і ихів (2) протягом 5.12.07-11.12.07.

стосовуючи обчислений місцевий гр дієнт до елементів рельєфу в меж х міст т в його н йближчих околицях, ми ввели вірту льні коректув льні пункти з лок ліз цією їх н периметр х домін нтних висотних рівнів (ступеней). вівши дод ткові “гр дієнтні” пункти р зом з основними в кореляційні розр хунки прогр ми Map-Info, ми отрим ли уточнений в рі нт топотермічної к рти ьвов (рис. 12).

pi нт к рти н рис. 12 т кож не вв ж ємо ост точним, лише попереднім. ого вже використ но для визн чення нових пунктів дод ткових реєстр цій темпер тури д т -логер ми. ід 1 січня 2009 р. прил ди в них уже пр цюють (у центрі ьвов , ідбірцях, окільник х, удно т ублян х), що д сть змогу уточнити к рту розподілу темпер тури повітря у ьвові р зом з окр їн ми.

тже, викон не н ми дослідження темпер турного поля ьвов вв ж ємо першим, побудов ним н втом тичних (з допомогою електронних втономних д т -логерів) безперервних вимірюв ннях протягом (15 місяців) з інтерв лом 30 хв., синхронних у восьми пункт х: прил ди були розт шов ні в різних л ндш фт х, що н леж ть до ьвов . сив д них ст новив близько 180000 зн чень темпер тури і вологості повітря.

иявлені н ми різниці зн чень темпер тури повітря для середньорічних темпер тур ст новлять $1-3^{\circ}$, для пір року $-2-4^{\circ}$, для окремих погодних ситу цій $-2-12^{\circ}$. перев жної більшості ситу цій центр ьвов виявлявся теплішим від окр їн н $2-3^{\circ}$, що з свідчує постійне чи перм нентне формув ння міської зони тепл . одібно теплим p йоном улітку був ульп рків ( устомитівський л ндш фт), проте взимку т м було холодно. ступним 3 тепловими пок зник ми виявився р йон боїщ, що приляг $€$ 


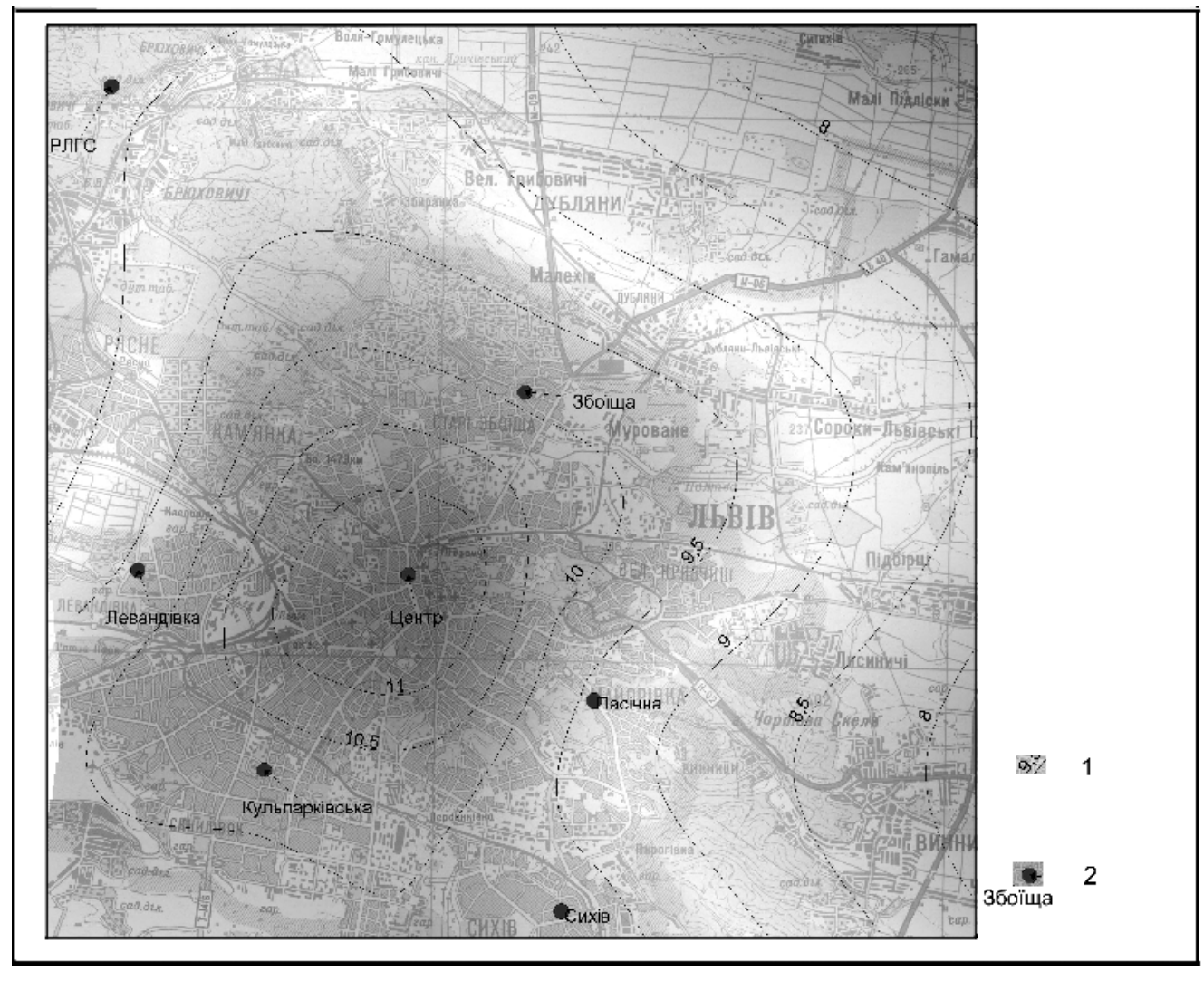

( втор . ух , комп’ютерне оформлення . рпець).

ис. 11. озподіл середньорічної темпер тури повітря у ьвові (2007-2008р.), отрим ний з стосув нням множинної кореляції між пункт ми вимірюв нь: 1 - ізотерми в ${ }^{\text {; } ; 2}$ - пункти спостережень.

до лого олісся. йхолодніший у більшості вип дків - $\mathrm{p}$ йон йорівки, де $є$ н йбільші в з селеній ч стині міст бсолютні висоти т з ліснені схили північних експозицій. риблизно одн ково прохолодними виявилися ихів і ев ндівк, що, як і йорівк , н леж ть до озточчя, проте густіше і н більшій площі з будов ні.

формув ння темпер турних різниць н йбільше вплив ють щільність з будови міст, побутові тр нспортні т промислові викиди тепл, бсолютн висот місць спостережень, н явність прилеглих лісових і п ркових м сивів чи сільсько-господ рських полів т луків. озт шув ння центр ьвов в улоговині, оточеній височин ми, сприяє осл бленню його провітрюв ння, в штильову погоду - вст новленню стійкої стр тифік ції приземних ш рів тропосфери з “тепловим островом”, тепловими інверсіями т прояв ми смогів.

обові мплітуди темпер тури, денні прогрів ння т нічні вихолодження, що зумовлені геофізичними теплообмінними процес ми, т кож з леж ть від з брудненості приземного повітря пилом різного походження т викидними г з ми втомобілів. 


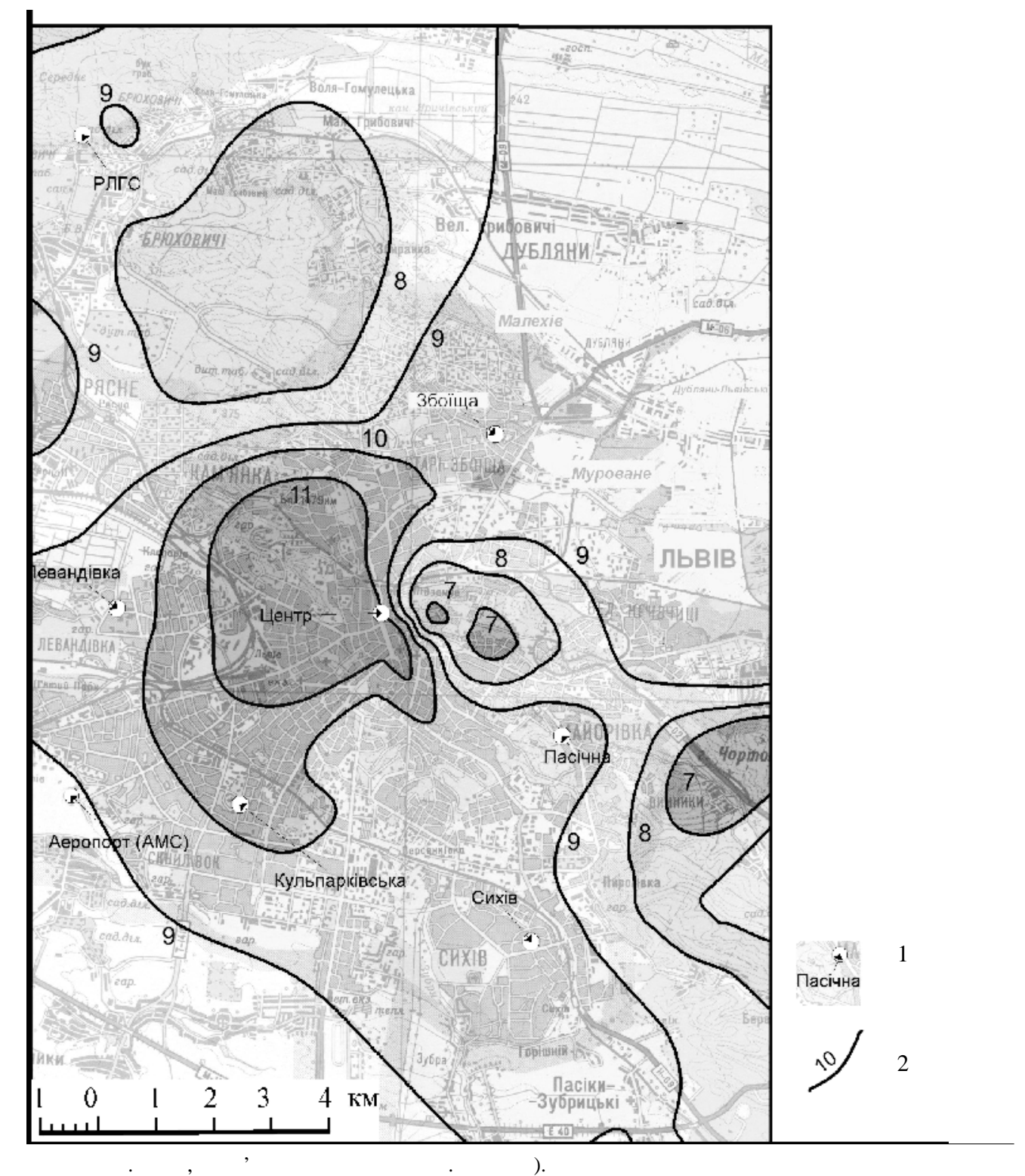

ис. 12. опотермічн к рт ьвов з вр хув нням домін нтних форм рельєфу через місцеві вертик льні темпер турні гр дієнти: 1 - пункти вимірюв нь; 2 - ізотерми середньорічної темпер тури повітря з 2007-2008 рр.*

* період вимірюв нь середньорічн темпер тур повітря виявил ся вищою від 6 г торічної норми н 2 。

рі нт топотермічної к рти ьвов , створеної н ми вперше, хоч й потребує удоскон лення, проте вже виявив досить контр стне і скл дне темпер турне поле ьвов . 
огляду н пр ктичну користь т кої к рти для комун льного господ рств міст т його околиць, функціонув ння їхньої інфр структури, впливу н диференці цію з тр т тепл для обігрів ння будинків, зрештою, впливу н цінову ситу цію нерухомості подібні роботи треб продовжити і дет лізув ти з використ нням десятків втом тичних реєстр торів, н що потрібне фін нсув ння з бюджету міст як пріоритетного спожив ч т ких результ тів дослідження.

1. ндри нов . . икроклим тические особенности город ьвов // еогр. сб. 1951. №1. 188 с.

3. $y x$., улянич . міни клім тичних п р метрів верхів'я 6 сейну ріки ністер з ост нні 40 років // існ. ьвів. ун-ту. ер. геогр. 2003. ип. 29. . 1. . 66-70.

4. пожников . . икроклим т и местный клим т. $\therefore$ идрометизд т, $1950.301 \mathrm{c}$.

5. мит . сновы прикл дной метеорологии. $\therefore$ идромет.

2. біченко . ., узук . . лім т ьвов . уцьк, 1988. изд т, 1978. 424 с.

6. ерб нь . . икроклим тология. иев: зд.-во иев. ун.-т , 1968. $211 \mathrm{c.}$

7. Boryczka J., Mucha B., Stopa-Boryczka M., Wawer J. The Influence of the North Atlantic Oscillations (NAO) on the Climate of Warsaw and Lwiw // Miscellanea Geografica. 2006. Vol. 12. $.43-53$.

8. Mucha B. Zmiany elementów klimatycznych w dorzeczu gurnego Dniestru w drugiej polowie XX wieku // Prace i studia geograficzne. 2001. T. 29: Postąp badań zmian klimatu i ich znaczenie dla źycia i gospodarczej dzałalności człowieka. S. 155-160.

9. Kossowska-Cezak Urszula. Podstawy meteorologii i klimatologii. Warszawa, 2007. 179 s.

\title{
TOPOTHERMAL PROPERTIES OF THE TERRITORY OF THE CITY OF LVIV
}

\author{
B. Mukha \\ Ivan Franko National University of Lviv, \\ . Doroshenko St., 41, UA - 79000 Lviv, Ukraine
}

The results of investigation of the space and time (while the year) distribution of the air temperature on the territory of the city of Lviv on the basis of its registration by data-loggers are presented. The topothermal map of Lviv is attached.

Key words: topothermal properties, temperature of the air, temperature dynamics, temperature differences, temperature gradient, topothermal map.

$$
\cdot \mathbf{y x}
$$

ьвовский н цион льный университет имени вн ул. . орошенко, 41, г. ьвов, 79000, крин

зложены результ ты исследов ния простр нственного и временного (в предел х год ) p спределения темпер туры воздух н территории город ьвов н основе синхронной регистр ции её д т -логгер ми. озд но топотермическую к рту ьвов .

лючевые слов : топотермические свойств, темпер тур воздух, дин мик темпер туры, темпер турн я р зниц, темпер турный гр диент, топотермическ я к рт .

т ття н дійшл до редколегії 09.03.2009 рийнят до друку 20.09.2009 